\title{
Susceptibility variations of multiple origins of loess from the Ily Basin (NW China)
}

\author{
CHEN Qu ${ }^{1,2}$, LIU XiuMing ${ }^{3,4^{*}}$, HELLER F $^{2}$, HIRT Ann M $^{2}$, LÜ Bin ${ }^{1}$, GUO XueLian ${ }^{1}$, \\ MAO XueGang ${ }^{1}$, CHEN JiaSheng ${ }^{1}$, ZHAO GuoYong ${ }^{1}$, FENG Hua ${ }^{1} \&$ GUO Hui ${ }^{1}$ \\ ${ }^{1}$ Key Laboratory of Western China's Environmental Systems, Lanzhou University, Lanzhou 730000, China; \\ ${ }^{2}$ Institute of Geophysics, ETHZ, CH-8092, Switzerland; \\ ${ }^{3}$ School of Geographical Sciences, Fujian Normal University, Fuzhou 350007, China; \\ ${ }^{4}$ Department of Environment and Geography, Macquarie University, Sydney NSW 2109, Australia
}

Received November 23, 2011; accepted March 8, 2012

\begin{abstract}
The magnetic susceptibility of loess from the Ily Basin, northwestern China shows maximum values in S0 paleosols but minimum values in other paleosols, the mechanism of which has been well debated. In this work, systematic magnetic measurements were made on a representative section from Neleke county. The results show that the loess horizons (L1, L2 and L3) have multi-domain magnetite grains of aeolian origin, $\mathrm{S} 0$ is characterized by production of pedogenetic ultrafine-grained ferrimagnetic minerals, and the other paleosols (S1, S2, and S3) are characterized by the formation of nonferrimagnetic minerals associated with waterlogging. The correlation between the low concentration of ferrimagnets, high paramagnetic content, high magnetic coercivity remanence, fine ferrimagnetic grain size and intensified pedogenesis suggest two competing processes of pedogenetic enhancement and pedogenetic depletion in the lower paleosols. Pedogenetic depletion dominates and is responsible for the low susceptibility. Changes in magnetic grain size distribution occur during pedogenetic depletion. The susceptibility variations are of multiple origins in the loess of the Ily Basin. Pedogenetic enhancement, pedogenetic depletion, and allochthonous input of magnetic minerals should all be taken into account to explain the variations of magnetic parameters.
\end{abstract}

magnetic susceptibility, magnetic depletion and enhancement, loess, Ily Basin, environmental magnetism

Citation: $\quad$ Chen Q, Liu X M, Heller F, et al. Susceptibility variations of multiple origins of loess from the Ily Basin (NW China). Chin Sci Bull, 2012, 57: 1844-1855, doi: 10.1007/s11434-012-5131-1

Low field magnetic susceptibility of loess records are widely used in paleoenvironmental research. The magnetic properties in loess records can be attributed to both original aeolian input and post-depositional pedogenesis [1]. Post-depositional pedogenesis can result in susceptibility enhancement or depletion and the interaction of these processes are site-specific [1,2]. Different models have been put forward to explain these susceptibility variations of different patterns. The pedogenetic enhancement model suggests that ultrafine ferrimagnetic minerals were formed during the pedogenesis process. This accounts for the high susceptibility in paleosols and low susceptibility in loess, and can be used

*Corresponding author (email: xliu @ fjnu.edu.cn) to explain loess deposits on the Chinese Loess Plateau [3-8]. The wind vigor model displays low susceptibility in paleosols and high susceptibility in loess. It argues that for loess from Alaska and Siberia, allochthonous input plays an important role in magnetic concentration and intensified wind vigor is responsible for increases in susceptibility [9-15]. However, pedogenesis influences not only the magnetic concentration but also the magnetic mineralogy and contributes at least partly to susceptibility variations in loess from Alaska and Siberia [16-20].

A negative relationship between susceptibility and the degree of pedogenesis was found in the Ily Basin, northwestern China [21-27]. In that location the susceptibility decreased dramatically in paleosols except S0, but was rela- 
tively high and constant in other horizons. YE Wei, SHI ZhengTao, SONG YouGui, XIA DunSheng et al. gave different explanations for the susceptibility variations but they did not adequately explain this depletion of susceptibility [21-27]. In this work, during September 2007 to May 2010, we collected loess samples in the Ily Basin during 3 field seasons. We focus on a loess section in Neleke County that exhibits the most significant susceptibility depletion in paleosols.

\section{Study area and stratigraphy}

The Ili Basin is located in central Eurasia (between $42^{\circ} 12^{\prime} \mathrm{N}$ and $44^{\circ} 48^{\prime} \mathrm{N} ; 80^{\circ} 10^{\prime}$ and $85^{\circ} 02^{\prime} \mathrm{E}$ ). Except for in the west, the Ily Basin is surrounded by high mountains, the average altitudes of which are $>3500 \mathrm{~m}$. The upper wind is controlled by westerlies throughout the year. Strong surface winds occur more frequently from April to July, originating from the west, the northwest and the southwest. Aligned almost parallel to the prevailing westerly winds and influenced by the great east-west altitudinal gradient, the Ily Basin is relatively abundant in rainfall [28]. The annual precipitation is not evenly distributed, falling higher in the east compared to the west. There is a linear relationship between annual precipitation and altitude. The increase in rate of annual precipitation is $40-60 \mathrm{~mm} / 100 \mathrm{~m}$ below the altitude of $1800 \mathrm{~m}$ [29]. At altitudes of $800 \mathrm{~m}$, the annual precipitation is ca. $300 \mathrm{~mm}$, at $1000 \mathrm{~m} \mathrm{ca} .600 \mathrm{~mm}$ and at $1800 \mathrm{~m}$ $>900 \mathrm{~mm}$ [28-31]. The zone of maximum precipitation lies between $1500 \mathrm{~m}$ and $1800 \mathrm{~m}$. Conversely, evaporation decreases as the altitude increases. The seasonal distribution of precipitation in the Ily Basin is different from that in the monsoon areas. Maximum precipitation occurs in May and November, while it is drier from July to September. However, the difference in precipitation between the months is not great except for in the mountainous areas. In the western plains, the seasonal distribution of precipitation is reasonably even, whereas in the eastern plains it is lower. In the mountainous areas, it becomes a single peak pattern, with precipitation in May and June higher than those in the other months. The average annual temperature in the Ily Basin is 2.6-9.2 ${ }^{\circ} \mathrm{C}$, with highest temperatures reached in July. The hotter seasons roughly coincide with the dry seasons, which are generally July and August. The typical zonal vegetation and soils in the Ily Basin are desert steppe and sierozems respectively. With increasing altitude and improving climate conditions towards the east, the desert steppe changes into mountain steppe and the sierozems change into kastarozems (1100-1500 m) and chernozems (1500-1800 m).

Loess is widely distributed in the Ili basin, ranging from $800 \mathrm{~m}$ on the river terraces to about $2000 \mathrm{~m}$ on the mountain slopes, with thicknesses generally between 20 and $60 \mathrm{~m}$. Paleosols are usually also present. The loess section in this study was located at Neleke County (NLK), $\left(43^{\circ} 39.4^{\prime} \mathrm{N}\right.$, $82^{\circ} 44.8^{\prime}, 1237 \mathrm{~m}$ ), on the northern terrace of Gongnaisi river, which is a branch of the Ili river. The section was $29.7 \mathrm{~m}$ thick, and well exposed because of recent road construction. The uppermost $0.5 \mathrm{~m}$ of the ection is S0. Besides S0, 3 lower paleosols were observed between 3.5 to $6.7 \mathrm{~m}$, 17.3 to $18.3 \mathrm{~m}$ and 24 to $29.7 \mathrm{~m}$. The paleosol at 3.5 to $6.7 \mathrm{~m}$ is red and abundant in snails. Below $17.3 \mathrm{~m}$, loess/paleosols are generally more developed, with 2 paleosols distinguishable from the overlying loess by their deep red color and fine grain size. Plenty of snails were found between $27.2 \mathrm{~m}$ and $28.5 \mathrm{~m}$, where the most intensive pedogenesis was observed. The loess-paleosol sequence is underlain by a gravel bed.

\section{Methods}

Optically stimulated luminescence dating (OSL dating) was conducted in the Institute of Geology, China Earthquake Administration.

A total of 594 powder samples were collected at $5 \mathrm{~cm}$ intervals from NLK section. All the samples were air-dried, and analyzed for grain size using a Mastersizer 2000 laser particles size analyzer. $5 \mathrm{~g}$ of each sample were packed into plastic boxes for the magnetic measurements. Low $(470 \mathrm{~Hz})$ and high $(4700 \mathrm{~Hz})$ frequency magnetic low field susceptibility were measured with a Bartington MS2 magnetometer. Anhysteretic remanent magnetizations (ARMs) were imprinted by a DTECH AF demagnetizer with a peak AF field of $100 \mathrm{mT}$ and DC bias field of $0.05 \mathrm{mT}$. Isothermal remanent magnetizations (IRMs) and saturation isothermal remanent magnetization (SIRM) were imparted by using a MMPM10 pulse magnetizer. Remanence measurements were made using a Minispin magnetometer. The backfield remagnetization of SIRM was carried out using reverse fields at $10 \mathrm{mT}$ steps and remanence coercivity $\left(B_{\mathrm{cr}}\right)$ calculated using linear interpolation. Backfield curves, hysteresis loops and thermomagnetic curves were determined on representative samples using a variable field translation balance (VFTB) and related parameters were attained [33]. These parameters included $M_{\mathrm{rs}}, M_{\mathrm{s}}$ (ferrimagnetic magnetization at $1 \mathrm{~T}$ ), $B_{\mathrm{cr}}$, $B_{\mathrm{c}}, B_{\mathrm{rh}}$ (median destructive field of the vertical hysteresis difference) [34], $S_{300}$, and para/diamagnetic slopes. The determinations and indications of the parameters are described in detail in [33] and [34]. The para/diamagnetic content was estimated by the ratio of para/diamagnetic magnetization at $1 \mathrm{~T}$ to $M_{\mathrm{s}}$. Temperature dependent susceptibility curves were measured with a KLY-3 Kappabridge. Two typical samples were treated with citrate-bicarbonate-dithionite (CBD) extraction to dissolve fine grained iron oxides. One was from L2 with high susceptibility and medium $B_{\mathrm{cr}}$, the other was from S2 with low susceptibility and high $B_{\text {cr. The same }}$ magnetic measurements were then performed on the postCBD samples. All the above measurements were conducted in the Key Laboratory of West China's Environmental Sys- 
tems, Lanzhou University. For typical samples, thermomagnetic curves were also measured with a Kappabridge and Backfield IRM curves with an ASC Magnetizer (Model IM-10-30) and a 2G Enterprises Cryogenic magnetometer in the Laboratory for Natural Magnetism, Institute of Geophysics, ETHZ, Switzerland.

\section{Results}

\subsection{OSL Dates}

An OSL age of $>100 \mathrm{ka}$ was been obtained at $8.1 \mathrm{~m}$. Therefore the three lower paleosols were assigned and correlated as paleosols S1, S2 and S3 on the Chinese Loess Plateau. The age agrees with those of loess sections previously reported in the Ily Basin and along North Piedmont of Tianshan Mountains [21,32]. The stratigraphic divisions based on our fieldwork observations are roughly consistent with our laboratory results (Figure 1).

\subsection{Magnetic properties at room temperature}

Figure 1 shows the stratigraphy, mass specific low field susceptibility $(\chi)$, frequency-dependent susceptibility $\left(\chi_{\mathrm{fd}}\right)$, ARM susceptibility $\left(\chi_{\text {ARM }}\right.$, ARM normalized by the $50 \mathrm{mT}$ direct bias field) and grain size parameters versus depth for NLK. The $<10 \mu \mathrm{m}$ and $>63 \mu \mathrm{m}$ grain size fractions are inversely correlated $\left(r^{2}=0.66\right)$, and indicate that wind intensities were greater during glaciations than during interglacials [35]. The $<2 \mu \mathrm{m}$ grain size fraction, which is thought to respond to degree of pedogenesis [36], shows higher values in the lower half of the section, in agreement with our fieldwork observations. However, the magnetic parameters of NLK are not consistent with the stratigraphy. Maximum $\chi$ is observed in $\mathrm{S} 0$ and L1, which ranges from 5.3-7.9x $10^{-7} \mathrm{~m}^{3} \mathrm{~kg}^{-1}$. Below the L1/S1 boundary, $\chi$ is low, typically below $4.5 \times 10^{-7} \mathrm{~m}^{3} \mathrm{~kg}^{-1}$, except for the maxima at ca. 10.5 $\mathrm{m}$ and $18.7 \mathrm{~m}$. The $\chi_{\mathrm{fd}}$ and $\chi_{\mathrm{ARM}}$ are high only in S0, but are low with little fluctuation in the other horizons. The peaks of $\chi$ between $9.8-11.4 \mathrm{~m}$ and ca. $18.7 \mathrm{~m}$ can be correlated to grain size extreme values, suggesting the susceptibility in these horizons is enhanced because of intensified wind vigor. The low $\chi_{\mathrm{fd}}$ and $\chi_{\mathrm{ARM}}$ values indicate that pedogenesis of $\mathrm{S} 1, \mathrm{~S} 2$ and S3 does not produce a high content of ultrafine SP and SSD ferrimagnetic minerals [37-41]. Wind vigor alone, however, can neither explain the discrepancy between S0 and the other paleosols nor adequately account for susceptibility variations.

The parameters that are sensitive to magnetic composition are shown in Figure 2. $B_{\text {cr }}$ of loess from the Chinese Loess Plateau is typically between $20-50 \mathrm{mT}$ and is higher in loess than in the paleosols [42-43]. At Neleke, the $B_{\text {cr }}$ curves demonstrate the discrepancy between S0 and the other paleosols. S0 shows minimum $B_{\text {cr }}$ at $44-54 \mathrm{mT}$. The loess horizons have higher $B_{\text {cr }}$ than S0, which can be interpreted to be low temperature oxidization [44-48]. S1, S2 and S3 display a maximum $B_{\mathrm{cr}}$ typically ranging from 62-69 $\mathrm{mT}$, indicating higher concentrations of hard minerals compared to S0. In addition, the $B_{\mathrm{c}}$ curve is similar to the $B_{\text {cr }}$ curve. The $S_{300}$ curves also suggest a relatively high

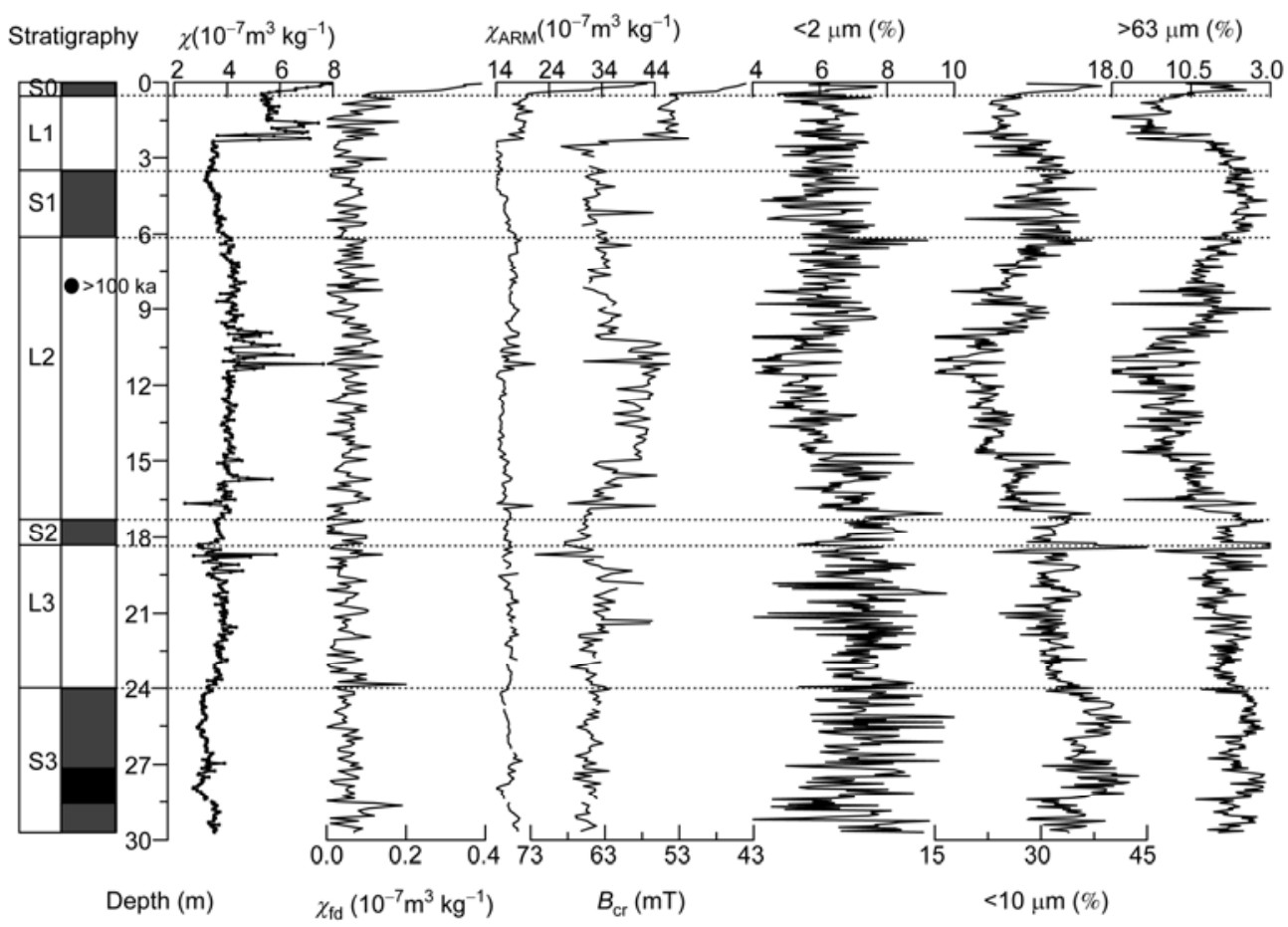

Figure 1 Stratigraphy, OSL age (solid dot), $\chi, \chi_{\mathrm{fd}}, \chi_{\mathrm{ARM}}, B_{\mathrm{cr}}$ and grain size parameters of NLK. 


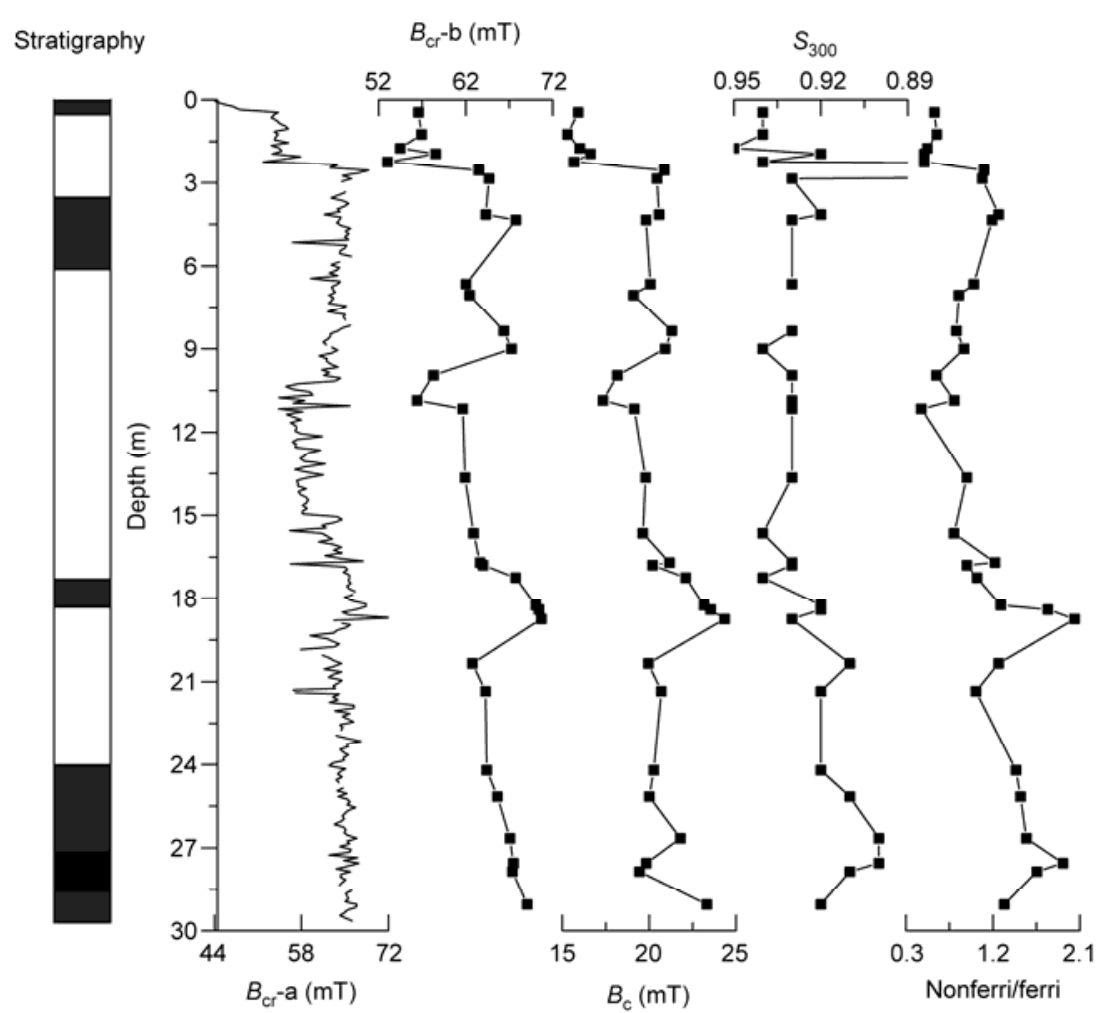

Figure 2 Parameters that are sensitive to magnetic mineral composition. $B_{\mathrm{cr}}$-a was measured using a MMPM10 pulse magnetizer and a Minispin magnetometer. $B_{\mathrm{cr}}-\mathrm{b}$ was measured using a VFTB.

content of harder minerals in S1, S2 and S3 [49].

The ratio of para/diamagnetic magnetization to ferrimagnetic magnetization at $1 \mathrm{~T}$ (nonferri/ferri) shows the same variation pattern to $B_{\mathrm{cr}}$ and $B_{c}$, with low values in S0 and high values in the other paleosols. The differences between S0 and the other paleosols are mainly due to the paramagnetic content.

Magnetic hysteresis loops for representative NLK samples are shown in Figure 3. The loops of all samples are closed by $300 \mathrm{mT}$, consistent with a ferrimagnetic phase. The linear increase in magnetization at higher fields reflects the paramagnetic component [5]. The S1, S2 and S3 samples show a steeper increase than S0 and loess samples, indicating a larger paramagnetic component.

Backfield demagnetization curves of SIRM (1 T) for typical samples are shown in Figure 4. The SIRM of S3 is low because of its low concentration of ferrimagnets. S0, L2 and S3 reversely acquire $96 \%, 87 \%$ and $85 \%$ of their SIRM intensity respectively under a field of $0.3 \mathrm{~T}$, implying a soft magnetic component as the major carrier of magnetic remanence. S0 has a stronger soft magnetic component than L2 and $\mathrm{S} 3$. This is consistent with the $B_{\mathrm{cr}}$ values calculated by using linear interpolation, which are 49.5, 63.8 and $74.7 \mathrm{mT}$ for S0, L2 and S3 respectively. A gradual increase after the $300 \mathrm{mT}$ step can be observed in S3. It implies that the content of hard magnetic minerals in the lower paleosol is relatively high compared to $\mathrm{S} 0$ and L2.

\subsection{Thermomagnetic properties}

High temperature thermomagnetic curves (Figure 5) show that all samples have a predominant Curie temperature of $580^{\circ} \mathrm{C}$. Magnetite from the samples is thought to contribute mainly to the magnetic signals. The increase of magnetization at around $160^{\circ} \mathrm{C}$ is assigned to the presence of goethite, which transforms into hematite at $300-400^{\circ} \mathrm{C}$. Since all cooling curves run below the heating curves, the transformation of maghemite into hematite is thought to be mainly responsible for the decrease in magnetization at $300-400^{\circ} \mathrm{C}$ upon heating.

The higher magnetization over $600^{\circ} \mathrm{C}$ indicates higher concentrations of paramagnetic minerals and hematite in S1, S2 and S3. S0 and the loess samples show a steeper decrease of magnetization towards $580^{\circ} \mathrm{C}$, suggesting that the relative concentration of magnetite in S0 and the loess horizons is higher than that in $\mathrm{S} 1, \mathrm{~S} 2$ and $\mathrm{S} 3$.

Low-temperature susceptibility curves can detect the presence of multi-domain (MD) magnetite [40,41]. The Verwey transition of magnetite at around $-150^{\circ} \mathrm{C}$ is found in S0 as well as in the loess samples (Figure 6). In S1, S2 and S3 however, the Verwey transition is at the limit of detection. The weak winds during the interglacial periods apparently were not able to carry and deposit coarse magnetite grains, and wind vigor probably played an insignificant role for the susceptibility variations. S0 not only has a larger 

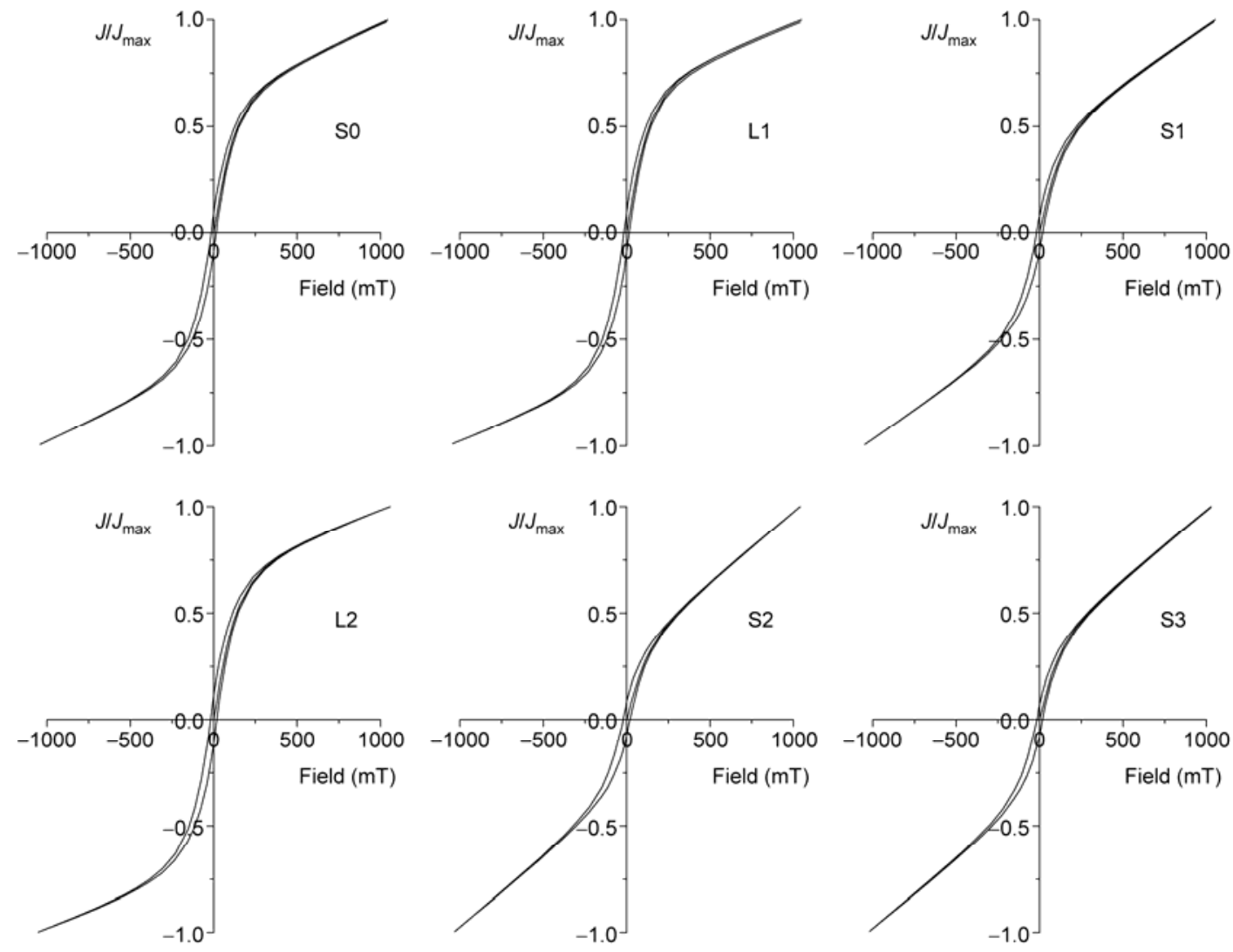

Figure 3 Hysteresis loops for representative samples from NLK, magnetization values were normalized to the maximum.

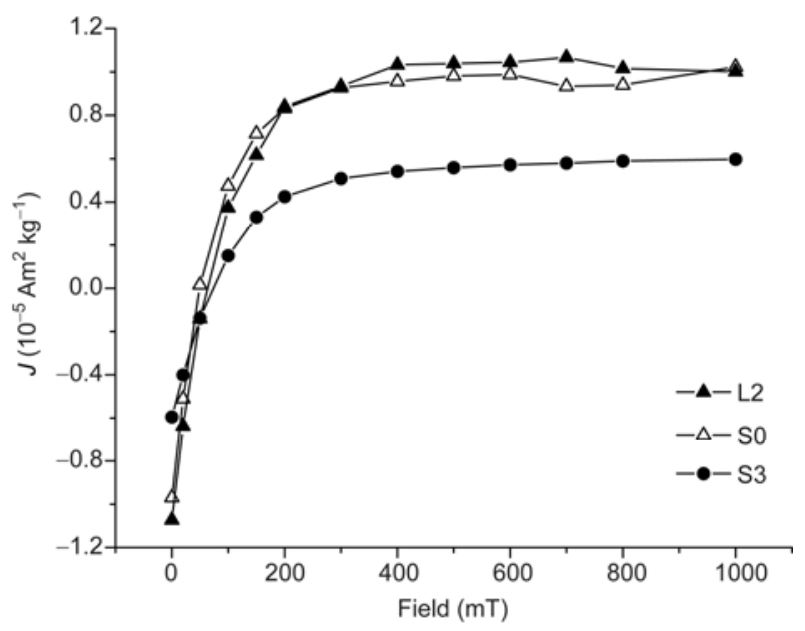

Figure 4 Backfield curves for representative samples from NLK. Backfield IRMs were measured at steps up to $1 \mathrm{~T}$ after the samples were given a $\operatorname{SIRM}(1 \mathrm{~T})$.

MD component but also a larger SP and SSD component than the lower paleosols, as the curves of $\chi_{\mathrm{fd}}$ and $\chi_{\mathrm{ARM}}$ suggest (see Figure 1). This cannot be explained adequately by using the pedogenetic enhancement or the wind vigor model. The concave-shape decrease of the $\kappa-T$ curves is caused by the paramagnetic material, whose susceptibility is inversely proportional to temperature. S1, S2 and S3 have higher con- centrations in paramagnetic content than the other horizons.

\subsection{Post-CBD measurements}

Citrate-bicarbonate-dithionite (CBD) extraction can efficiently dissolve fine-grained iron-oxides such as maghemite, magnetite goethite and hematite. Assuming that most pedogenetic magnetic grains are sufficiently small and most lithogenic magnetic grains are sufficiently large, the CBD procedure can be used to separate the pedogenetic component from the initial aeolian component [50,51]. For samples from the Chinese Loess Plateau, the residual following CBD treatment usually shows higher $B_{\mathrm{cr}}$ and $B_{\mathrm{c}}$ than the bulk samples [52], implying that the CBD-soluble fined-grained pedogenetic magnetic minerals have lower $B_{\mathrm{cr}}$ and $B_{\mathrm{c}}$. For NLK samples however, the experiments yielded opposite results (Table 1 ). The residual showed lower $B_{\mathrm{cr}}$ and $B_{\mathrm{c}}$ than the bulk samples, which indicated the extractable fine- grained pedogenetic magnetic minerals had higher $B_{\text {cr }}$ and $B_{\mathrm{c}}$. We found that CBD treatment on typical Siberian samples also showed a decrease in $B_{\mathrm{cr}}$ and $B_{\mathrm{c}}$ of the residual, suggesting a similarity between Neleke and Siberian loess (unpublished data).

\subsection{Magnetic grain size distribution}

Figure 7 shows parameters that are sensitive to magnetic 

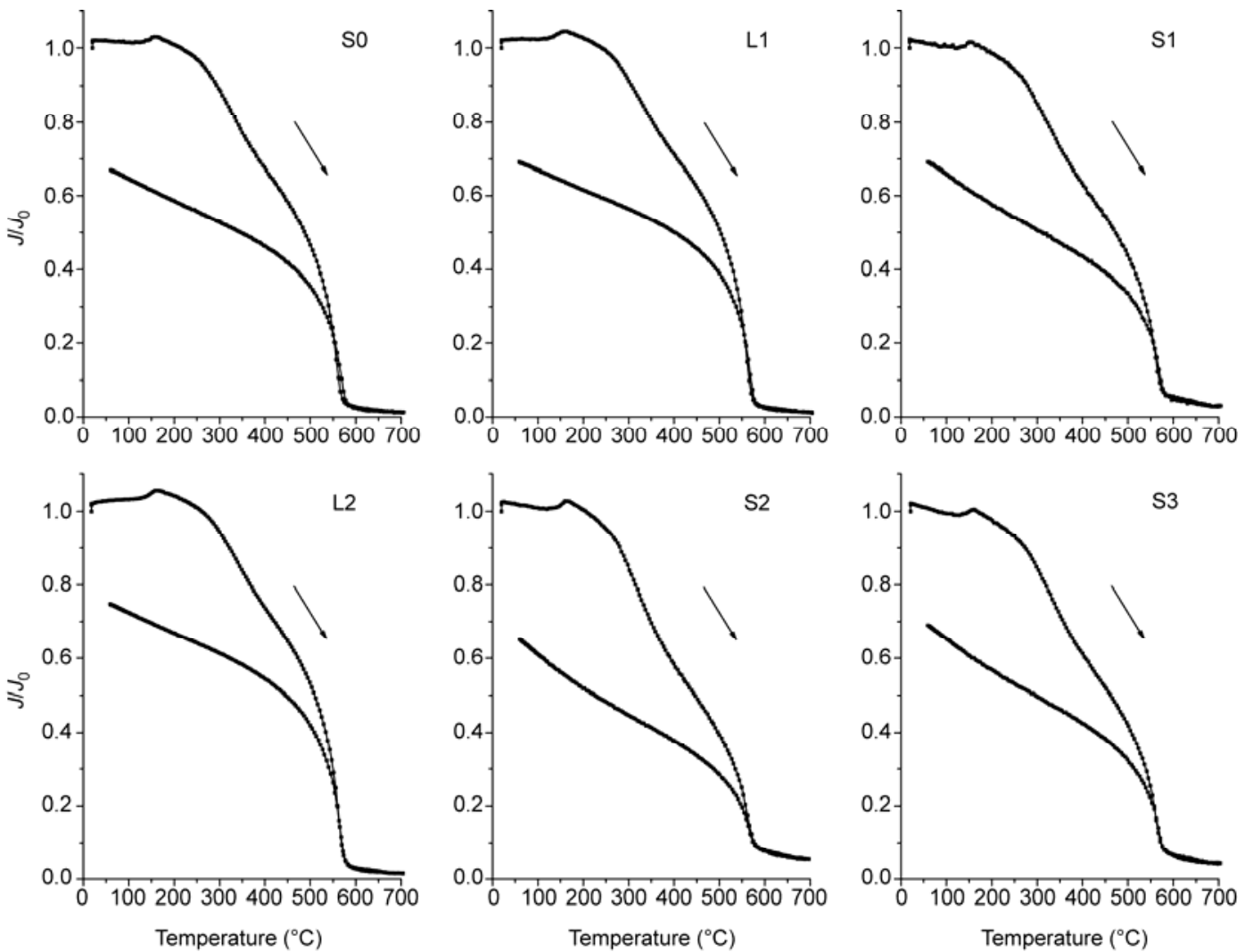

Figure $5 J-T$ curves for representative samples from NLK, magnetization values were normalized to those at room temperature.
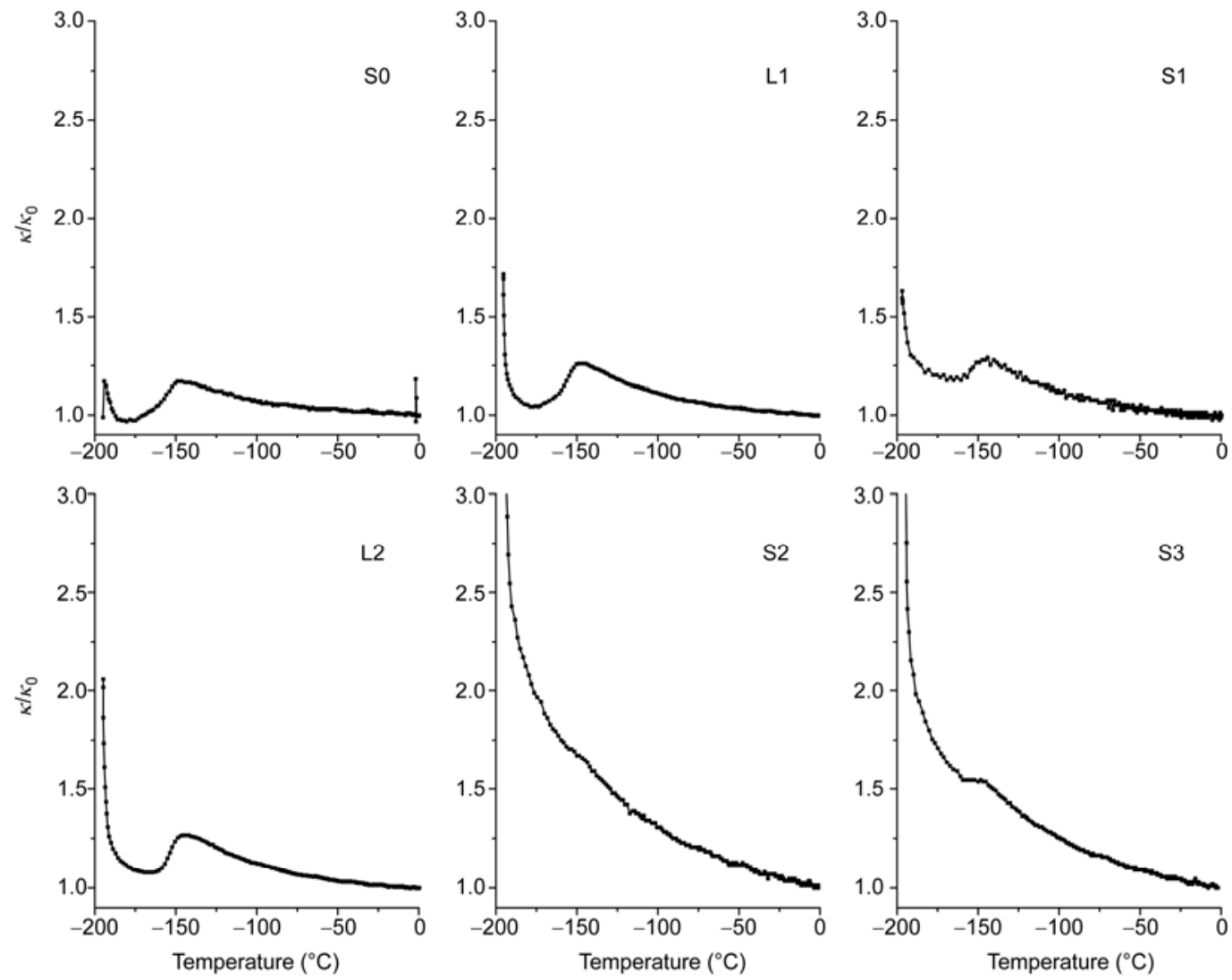

Figure 6 Low temperature $\kappa$-T curves for representative samples from NLK, susceptibilities were normalized to the values at room temperature. 
Table 1 Magnetic parameters for typical NLK samples (loess sample at $9.95 \mathrm{~m}$ and paleosol sample at $18.3 \mathrm{~m}$ ) before and after CBD treatment

\begin{tabular}{lccccccc}
\hline \multicolumn{1}{c}{ Sample } & $\chi\left(10^{-7} \mathrm{~m}^{3} \mathrm{~kg}^{-1}\right)$ & $\chi_{\mathrm{ARM}}\left(10^{-7} \mathrm{~m}^{3} \mathrm{~kg}^{-1}\right)$ & $B_{\mathrm{cr}}(\mathrm{mT})$ & $B_{\mathrm{c}}(\mathrm{mT})$ & $B_{\mathrm{cr}} / B_{\mathrm{c}}$ & $M_{\mathrm{rs}} / M_{\mathrm{S}}$ & $B_{\mathrm{rh}} / B_{\mathrm{cr}}$ \\
\hline Loess pre-CBD & 5.67 & 12.3 & 58.29 & 18.17 & 3.21 & 0.18 & 1.39 \\
loess post-CBD & 5.31 & 6.7 & 49.58 & 12.6 & 3.94 & 0.13 & 1.49 \\
Paleosol pre-CBD & 3.36 & 11.0 & 63.65 & 21.16 & 3.01 & 0.2 & 1.3 \\
Paleosolpost-CBD & 2.95 & 4.1 & 55.12 & 14.32 & 3.85 & 0.15 & 1.45 \\
\hline
\end{tabular}

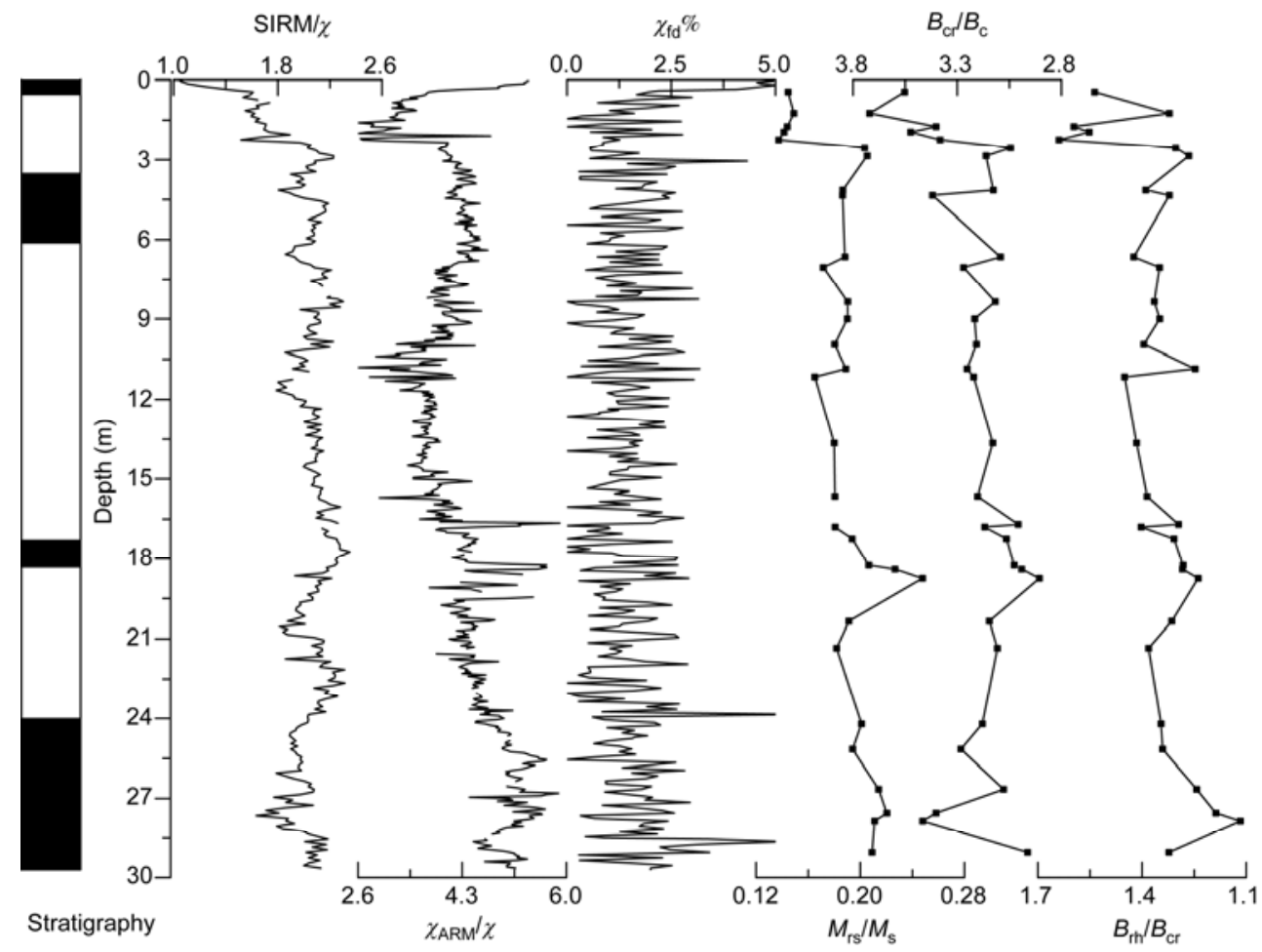

Figure 7 Parameters that are sensitive to magnetic grain size for NLK.

grain size. For S0, SIRM/ $\chi$ is the lowest, compatible with the relatively high $\chi_{\mathrm{fd}}$ values. The correlation between $\mathrm{SIRM} / \chi$ and $\chi_{\mathrm{ARM}} / \chi$, demonstrate higher values in paleosols and lower values in loess, implies the change in magnetic grain size occurs mainly in the range from PSD to SSD [40,41]. At around $18.3 \mathrm{~m}$ and between $24-28.5 \mathrm{~m}$, relatively low SIRM $/ \chi$ but high $\chi_{\mathrm{ARM}} / \chi$ was observed. This can be partly ascribed to paramagnetic minerals, which contribute to $\chi$ but not to SIRM. Consistent highs and lows can be observed in the curves. At around $19 \mathrm{~m}$ and the bottommost part (below $24 \mathrm{~m}$ ), noticeably finer grain sizes were observed, responding to the low susceptibility, high content of hard component and para/diamagnetic component exhibited above. On the Chinese Loess Plateau, neoformation of pedogenetic fine grains results in high susceptibility. However, in NLK, pedogenetic fine grain size coincides with low susceptibility, except for S0. This suggests that the absolute concentration of ferrimagnetic component is low while the relative content of fine-grained ferrimagnets of pedogenetic origin is high and thus there are two competing processes of pedogenetic enhancement and pedogenetic depletion. The pedogenetic enhancement process results in fine ferrimagnetic grain size. The pedogenetic depletion process results in neoformation of (or transformation into) hard magnetic minerals and para/ diamagnetic minerals.

Figures 7-10 show that the magnetic grain size distributions in S1, S2 and S3 are different from those in S0. The same distribution as the loess from the Chinese Loess Plateau was exhibited in S0, with a linear relationship between $\chi_{\mathrm{ARM}}, \chi_{\mathrm{ARM}} / \chi, \chi_{\mathrm{fd}}, \chi_{\mathrm{fd}} \%$ and $\chi$ [53-59]. For the other paleosols, the linear relationship between $\chi_{\text {ARM }}$ and $\chi$ was reversed (Figure 10) and the linear relationship between $\chi_{\text {ARM }}$ and $\chi_{\mathrm{fd}}$ was absent (Figure 8). $\chi_{\mathrm{ARM}} / \chi$ can be as high in S3 as in topsoils, while $\chi_{\mathrm{fd}} \%$ is consistently low below S0 (Figure 7). This implies that the grain size distribution in the SP-SD range is not consistent through the section. Relative content of SSD grains vary in proportion to the degree of pedogenesis, but the relative content as well as the absolute content of SP grains is consistently very low except for S0 (Figures 1 and 7). For horizons from L1 to S3, the samples 


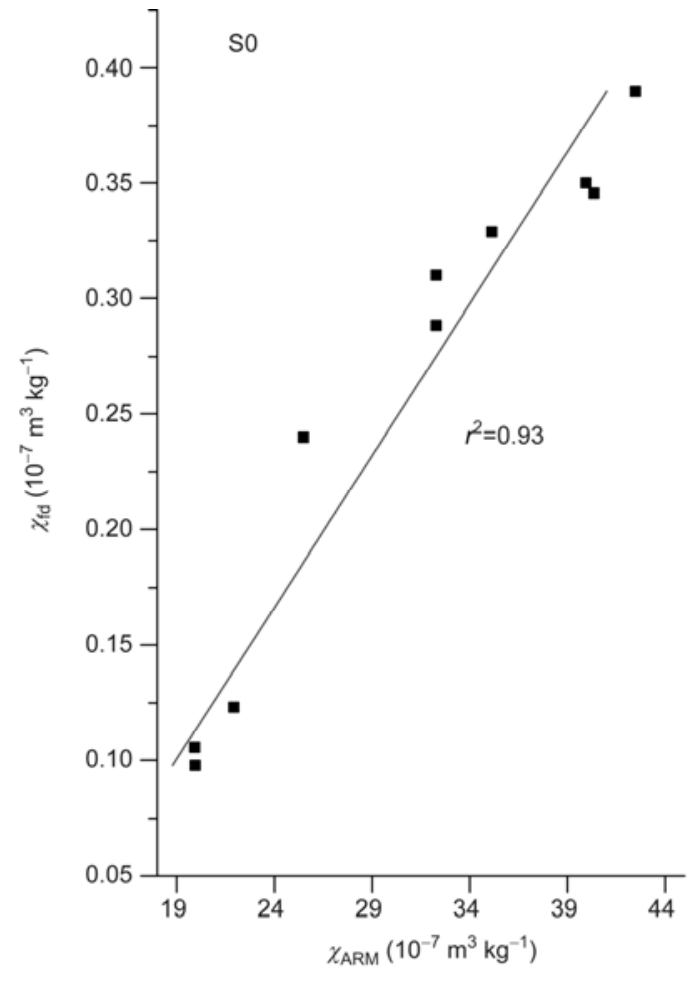

Figure 8 Plots of $\chi_{\text {ARM }}$ and $\chi_{\mathrm{fd}}$ for S0 (left) and the other paleosols (right).

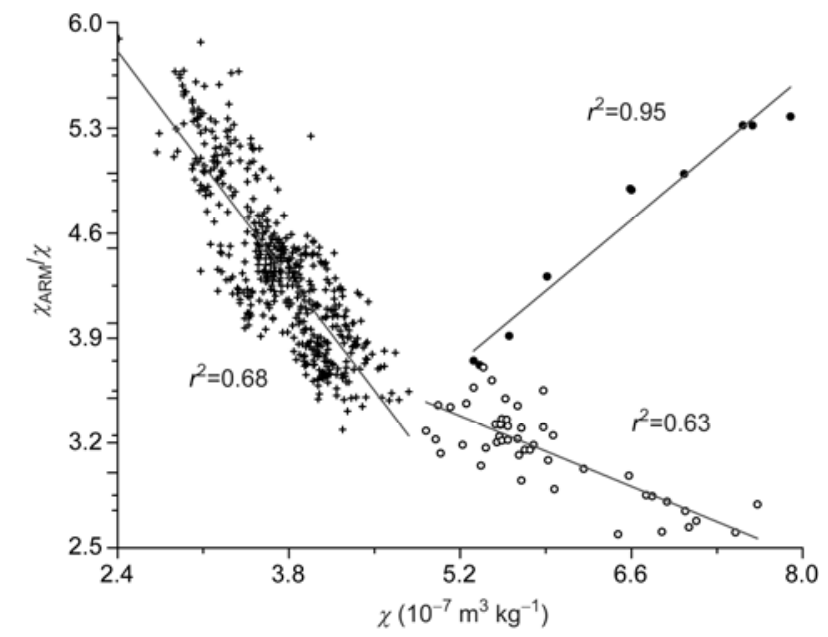

Figure 9 Plots of $\chi_{\mathrm{ARM}} / \chi$ and $\chi$ for L1-S3 samples with $\chi$ lower than 4.8 $\times 10^{-7} \mathrm{~m}^{3} \mathrm{~kg}^{-1}$ (crosses), L1-S3 samples with $\chi$ higher than $4.8 \times 10^{-7} \mathrm{~m}^{3} \mathrm{~kg}^{-1}$ (circles), and S0 (solid dots).

with $\chi<4.8 \times 10^{-7} \mathrm{~m}^{3} \mathrm{~kg}^{-1}$ show a much steeper decrease in $\chi_{\mathrm{ARM}} / \chi$ with increasing $\chi$ than the samples with $\chi>4.8 \times$ $10^{-7} \mathrm{~m}^{3} \mathrm{~kg}^{-1}$ (Figure 9). The latter mostly respond to typical loess horizons dominated by strong winds at $0.2-2 \mathrm{~m}$ and 9.8-11.4 $\mathrm{m}$ (Figure 1). This data suggests that the interpretation of $\chi_{\mathrm{ARM}} / \chi$ variations should be horizon-specific.

$\chi_{\text {ARM }}$ vs. $\chi$ (King plot) can be used to detect changes in the relative grain-size and amount of magnetite in natural materials [49]. The pedogenetic grains and aeolian grains
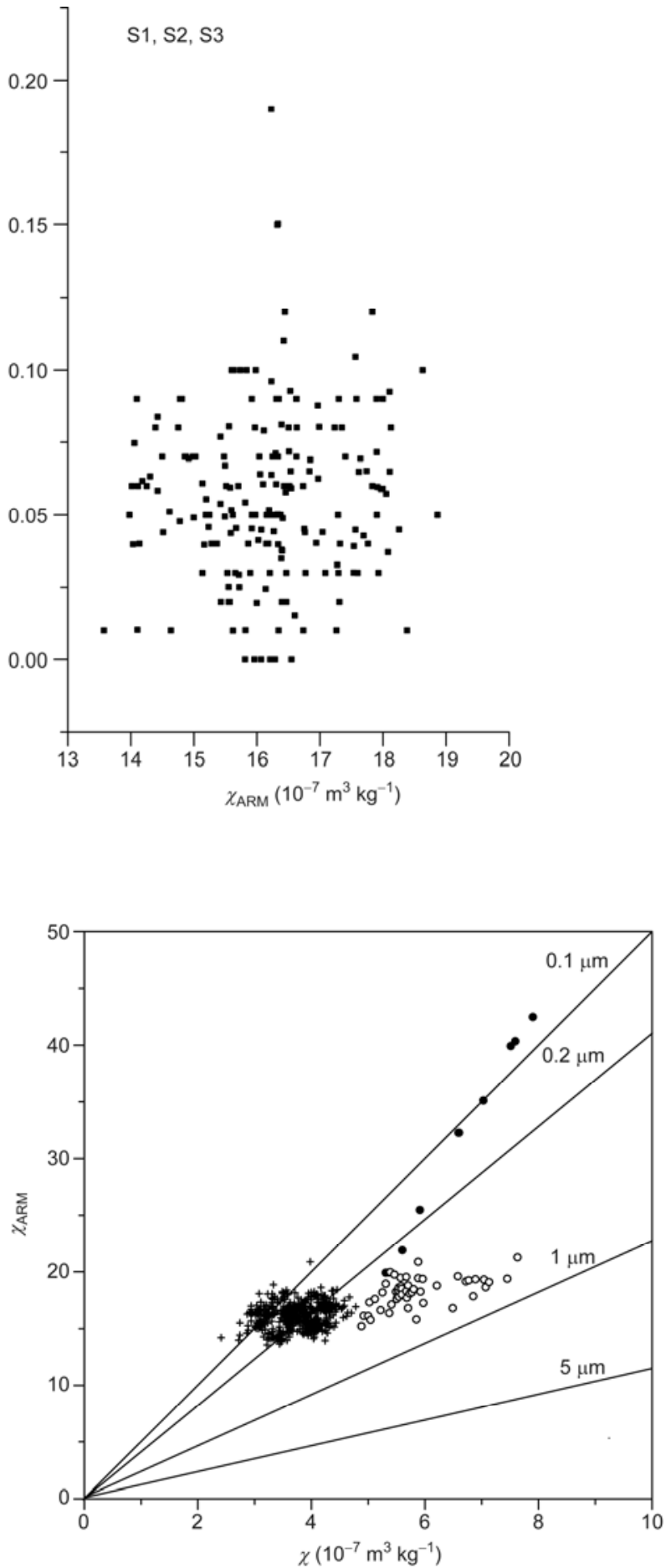

Figure 10 King plot of NLK. Solid dots are S0 samples, circles are L1$\mathrm{S} 3$ samples with $\chi$ higher than $4.8 \times 10^{-7} \mathrm{~m}^{3} \mathrm{~kg}^{-1}$, crosses are L1-S3 samples with $\chi$ lower than $4.8 \times 10^{-7} \mathrm{~m}^{3} \mathrm{~kg}^{-1}$.

have different grain size distributions. The minimum grain size limit for the original input of aeolian origin is about $0.1 \mu \mathrm{m}$ whereas the transitional grain size range is $0.1-0.3 \mu \mathrm{m}$ [54]. Therefore it is possible to use the King plot to separate samples containing magnetic grains of pedogenetic origin from those containing magnetic grains of aeolian origin. S0 
samples at Neleke are in $<0.2 \mu \mathrm{m}$ area, or in the area between 0.2 and $1 \mu \mathrm{m}$ but adjacent to the $0.2 \mu \mathrm{m}$ boundary (Figure 10). The two distinct populations of the $\mathrm{L} 1$ to $\mathrm{S} 3$ samples appear in the dataset. Samples with $\chi>4.8 \times 10^{-7} \mathrm{~m}^{3} \mathrm{~kg}^{-1}$ scatter in $>0.2 \mu \mathrm{m}$ area are indicative of aeolian origin. This agrees with the assumption that grains $>0.3 \mu \mathrm{m}$ can be regarded as aeolian ones [54]. Like S0, samples with $\chi<4.8 \times 10^{-7} \mathrm{~m}^{3} \mathrm{~kg}^{-1}$ aggregate in or near the left upper $<0.2 \mu \mathrm{m}$ area, indicate that the magnetic particles are of pedogenetic origin. Compared to S0 samples, which demonstrate a rapid rise in $\chi_{\text {ARM }}$ with increasing $\chi$, the other samples show relatively constant $\chi_{\text {ARM }}$. This suggests that the increase in susceptibility of the scattered samples on the right can be ascribed to coarse PSD and MD grains of aeolian origin, the decrease in susceptibility of the aggregated samples on the left can be at least partly attributed to the pedogenetic depletion process, which results in transformation into nonferrimagnets of PSD and SP ferrimagnets.

\section{Discussion}

MD grains in S0 and loess samples of Neleke can be ascribed to as input originating from intensified wind vigor or of proximal lithogenic. The source area of the loess in the Ily Basin is thought to be the deserts in central Asia [60]. However, recent studies show that the surface soils in the Ily Basin vary significantly in magnetic grain size and in some localities are very coarse [61]. This suggests that local sources like river valleys may also contribute to the magnetic signals. The wind vigor and local source materials are partly responsible for the magnetic variations [62]. Regardless of the coarse allochthonous component, the magnetic signals are controlled by the pedogenetic ultrafine grains in SO.

Pedogenetic enhancement is observed in different loess strata at different altitudes. All S0 paleosols demonstrate the magnetic properties that are in line with the pedogenetic enhancement model. However, the sedimentation rates from all the paleosols studied are quite different, with thicknesses ranging from ca. 0 to more than $2 \mathrm{~m}$. S1 paleosols from some sections by the Gongnaishi river valley were thought to exhibit a decrease in $\chi$ [21-27]. However, the sharp and uneven boundaries between the $\chi$ highs and lows cannot be correlated to the strata or the pedogenetic intensity. Generally, $\chi$ shows both maximum and minimum values in $\mathrm{S} 1$. The variations in $\chi_{\mathrm{fd}}$ are similar to those of $\chi$. Therefore pedogenetic enhancement is partly present in S1. At high latitudes, $\chi$ and $\chi_{\mathrm{fd}}$ can be correlated to pedogenetic intensity, suggesting pedogenetic enhancement due to a more humid environment. In sharp contrast to NLK, pedogenetic enhancement was found in all the paleosols.

The loess in the plain area of the Ili bain is similar to that in the west edge of the Chinese Loess Plateau, showing the presence of coarse magnetic grains and pedogenetic enhancement. However, in the Ily Basin, $\chi$ and $\chi_{\mathrm{fd}} \%$ are relatively low. For the section in Jiuzhoutai, Lanzhou, where the zonal soils are also sierozems, the annual precipitation is about $300 \mathrm{~mm}$ and the annual temperature is $11.3^{\circ} \mathrm{C}, \chi$ and $\chi_{\mathrm{fd}} \%$ are about $9 \times 10^{-7} \mathrm{~m}^{3} \mathrm{~kg}^{-1}$ and $>8$, respectively, in surface soils and the upper part of S0 [63]. For surface samples in the plain area of the Ily Basin (at around $850 \mathrm{~m}$ ), where the annual precipitation is $350-480 \mathrm{~mm}$ and annual temperature is about $8^{\circ} \mathrm{C}, \chi$ and $\chi_{\mathrm{fd}} \%$ are $8 \times 10^{-7} \mathrm{~m}^{3} \mathrm{~kg}^{-1}$ and $2-6$, respectively [22-26]. The values decrease rapidly with depth in S0. The lower $\chi_{\mathrm{fd}} \%$ can be explained by the larger component of original aeolian input in the Ily Basin. For surface samples at higher altitudes (1400-1875 m) in the Ily Basin, where the annual precipitation is approximately 550$900 \mathrm{~mm}$ and annual temperature is $<5^{\circ} \mathrm{C}, \chi$ and $\chi_{\mathrm{fd}} \%$ are $8 \times$ $10^{-7} \mathrm{~m}^{3} \mathrm{~kg}^{-1}$ and $<6$ respectively [22-24]. The values also decrease rapidly downwards in S0. In the case of Neleke section $(1237 \mathrm{~m}), \chi$ and $\chi_{\mathrm{fd}} \%$ of surface soils are $8 \times 10^{-7} \mathrm{~m}^{3} \mathrm{~kg}^{-1}$ and $<4$ respectively. In northwestern China, there is a linear relationship between altitude and the grain size of loess deposits [64]. Therefore, less input of coarse magnetic grains is expected at higher altitude. In addition, dense vegetation at higher altitude may prevent proximal deposition. The original input is probably less and a higher $\chi_{\mathrm{fd}} \%$ is expected even if the pedogenetic enhancement is of the same degree. However data from the loess in the Ily Basin show little increase in $\chi$ and $\chi_{\mathrm{fd}} \%$ with increasing altitude and precipitation. This indicates that low temperature may lessen pedogenetic enhancement. High precipitation does not necessarily result in high content of pedogenetic ultrafine grains if the temperature is not favorable. The relatively low pedogenetic concentration in the basin is possibly attributed to the lower temperature and the absence of coincidence between hot seasons and rainy seasons.

The classic pedogenetic enhancement model proposes that ultrafine maghemite grains dominate and come from oxidation of ultrafine magnetite grains [65], which are in turn formed via inorganic [3] or bacterially mediated pathways [66] during intermittent wetting-drying periods in soils $[67,68]$. The consistent magnetic grain size distribution of pedogenetic particles might be controlled by the constant soil $\mathrm{pH}$ on the Chinese Loess Plateau because of the high buffering capacity of high carbonate content. It has been generally accepted that the rainfall component of the climate system is a key influence on loess magnetic properties $[67,68]$. Temperature may play an insignificant role in pedogenetic enhancement on the Loess Plateau [58]. Alternately, a recent hypothesis has proposed that the ferrihydrite $\rightarrow$ SP maghemite $\rightarrow$ SD maghemite $\rightarrow$ SD hematite transformation may constitute a major pathway accounting for pedogenetic enhancement [69-72]. The consistent magnetic grain size distribution may be due to the representation of all intermediate stages in the formation and growth of ma- 
ghemite, which in turn results from the continuous formation of ferrihydrite in favorable temperature and moisture conditions. The production rate of the ultrafine maghemite is sensitive to temperature change. Therefore temperature is expected to have effects on $\chi$ and $\chi_{\mathrm{fd}} \%$. However, there is controversy over these hypotheses. Further work is required to interpret whether the influence of temperature on loess magnetic properties and the possible subtle difference between loess in the Ily Basin and the Chinese Loess Plateau with respect to pedogenetic enhancement.

A sharp decrease in susceptibility was observed in the lower paleosols of various loess sections along the Gongnaishi River valley [22-26]. Minimum $\chi$ of the whole sections were found typically in the most strongly developed horizons. Relatively high $\chi_{\mathrm{fd}}$ and $\chi_{\mathrm{ARM}}$ and low $\chi$ were found in the paleosols, suggesting that pedogenetic enhancement competes with pedogenetic depletion but cannot overcome the decrease in $\chi[24,26]$. Different from those observations, the Neleke section displays low values of $\chi_{\mathrm{fd}}$ and $\chi_{\mathrm{ARM}}$ as well as $\chi$, indicative of more intensive pedogenetic depletion. Waterlogging in loess deposits was reported along the valley. In the fieldwork, waterlogging can be revealed by ferruginous mottles and abrupt changes in color. We found that the durations of waterlogging were section specific and the magnetic properties of the waterlogged paleosols are very similar. For Neleke section, we suggest that the pedogenetic depletion was due to continuous waterlogging or overwet conditions. During the interglacial periods, the westerlies moved northwards and controlled the climate in the Ily Basin, which was humid and mild. The river plains and depressions were susceptible to waterlogging due to increased precipitation and melt water.

The Neleke section is located between the small hills. Given this favorable topography, the paleosols were probably constantly waterlogged and poorly drained. Intermittent reduction is required for the formation of the ferrimagnets. Constant oxidation or reduction favors formation and accumulation of non-ferrimagnets [1,17-20,41,73]. The wet reducing conditions in NLK resulted in destruction of ferrimagnets and the formation of non-ferrimagnets. Compared to typical Siberian loess, NLK shows a larger component of paramagnetic minerals and a smaller component of hard minerals with high $B_{\text {cr }}[15,74]$. In south Siberia, all paleosols, including S0, usually display low susceptibility. This can be explained by the local climate, which causes very moist conditions in the soils [20]. However, during glacial periods, the climate was conjectured to be drier, resulting in relatively oxidizing conditions and preservation of ferrimagnets. Therefore the susceptibility variations of south Siberian loess can be roughly correlated to climate change of a broad area. In the Ily Basin, the susceptibility variations are of multiple origins and more complicated. The interpretation of susceptibility should be site and horizon specific. However, $\chi_{\mathrm{ARM}} / \chi$ of NLK can reflect climate change as suggested by its correlation with grain size and pedogenetic development. For the lower paleosols of NLK, $\chi_{\text {ARM }} / \chi$ fluctuates while $\chi_{\mathrm{fd}} \%$ is consistently very low. This suggests that SSD grains preserved while SP grains were destroyed, which can be ascribed to the difference of specific surface area between SP grains and SD grains. SP grains are expected to be more easily dissolved than coarse grains. Conversely, it was reported that pedogenesis decreased $\chi$ and increased $\chi_{\mathrm{fd}} \%$ at some degree of humidity and the depletion of both $\chi$ and $\chi_{\mathrm{fd}} \%$ did not occur until after the water content became excessive as waterlogging progressed [73]. This suggests that pedogenetic depletion begins with destruction of coarse grains, agreeing with the correlation between relatively high $\chi_{\mathrm{fd}} \%$ and low $\chi$ in paleosols from some sections in the Ily Basin [24,26]. The absence of MD grains in the lower paleosols of NLK is attributed to less coarse grained aeolian input, and possibly the pedogenetic destruction of coarse grains associated with excessive wet conditions. Further work is required to better understand the mechanism of magnetic depletion in the Ily Basin.

\section{Conclusions}

Changes in the local environment can complicate loess magnetic enhancement mechanism. The susceptibility variations in the Ily Basin appear to be of multiple origin. The interplay between the formation of ferrimagnets and nonferrimagnets is probably competitive and may thus determine the degree of magnetic enhancement. Pedogenetic depletion dominates in this area and is significantly responsible for the susceptibility variations of paleosols, which is due to the formation of nonferrimagnets and conversion of ferrimagnets to nonferrimagnets in excessive wet conditions. Changes in magnetic grain size distribution occur during pedogenesis depletion. To interpret the variations of susceptibility and other magnetic parameters such as $\chi_{\mathrm{fd}}$ and $\chi_{\mathrm{ARM}}$, all the possibilities of pedogenetic enhancement, pedogenetic depletion, and allochthonous input of magnetic minerals must be considered.

We thank Dr. Alexey Yurievich Kazansky and Dr. Galina Gel'evna Matasova for constructive discussions and two reviewers for their helpful comments and suggestions. We also thank Dr. Liu Jinfeng for conducting the OSL dating. This work was supported by the National Natural Science Foundation of China (40830105, 40772109, 40721061) and the China Scholarship Council.

1 Maher B A. Magnetic properties of modern soils and Quaternary loessic paleosols: Paleoclimatic implications. Palaeogeogr Palaeocl, 1998, 37: 25-54

2 Sun J M, Liu T S. Multiple origins and interpretations of the magnetic susceptibility signal in Chinese wind-blown sediments. Earth Planet Sci Lett, 2000, 180: 287-296

3 Maher B A, Taylor R M. Formation of ultrafine magnetite in soils. Nature, 1988, 336: 368-370

4 Zhou L P, Oldfield F, Wintle A G, et al. Partly pedogenic origin of 
magnetic variations in Chinese loess. Nature, 1990, 346: 737-739

5 Liu X M, Shaw J, Liu T S, et al. Magnetic mineralogy of Chinese loess and its significance. Geophys J Int, 1992, 108: 301-308

6 Evans M E, Heller F. Magnetic enhancement and paleoclimate: study of a loess/paleosol couplet across the Loess Plateau of China. Geophys J Int, 1994, 117: 257-264

7 Evans M E, Heller F. Magnetism of loess palaeosol sequence: recent developments. Earth-Sci Rev, 2001, 54: 129-144

8 Liu Q S, Jackson M J, Banerjee S K, et al. Mechanism of magnetic susceptibility enhancements of the Chinese loess. J Geophys Res, 2004, 109: B12107

9 Begét J E, Hawkins D B. Influence of orbital parameters on Pleistocene loess deposition in central Alaska. Nature, 1989, 337: 151-153

10 Begét J, Stone D, Hawkins D. Paleoclimate forcing of magnetic susceptibility variations in Alaskan loess. Geology, 1990, 18: 40-43

11 Begét J. Tephrochronology and paleoclimatology of the last interglacial cycle recorded in Alaska loess deposits. Quat Int, 1996, 34-36: 121-126

12 Chlachula J, Evans M E, Rutter N W. A magnetic investigation of a late Quaternary loess/paleosol record in Siberia. Geophys J Int, 1998, 132: $128-132$

13 Kravchinsky V A, Zykina V S, Zykin V S. Magnetic indicator of global paleoclimate cycles in Siberian loess-paleosol sequences. Earth Planet Sci Lett, 2008, 265: 498-514

14 Zhu R X, Alexey K, Galina M, et al. Rock-magnetic investigation of Siberia loess and its implication. Chin Sci Bull, 2000, 45: 2192-2198

15 Matasova G, Petrovský E, Jordanova N, et al. Magnetic study of Late Pleistocene loess/palaeosol sections from Siberia: Palaeoenvironmental implications. Geophys J Int, 2001, 147: 367-380

16 Zhu R X, Matasova G, Kazansky A, et al. Rock magnetic record of the last glacial-interglacial cycle from the Kurtak loess section, southern Siberia. Geophys J Int, 2003, 152: 335-343

17 Liu X M, Hesse P, Rolph T, et al. Properties of magnetic mineralogy of Alaskan loess: Evidence for pedogenesis. Quat Int, 1999, 62: 93102

18 Liu X M, Hesse P, Rolph T. Pedogenic destruction of ferrimagnetics in Alaskan loess deposits. Australian J Soil Res, 2001, 39: 99-115

19 Liu X M, Xia D S, Liu D S, et al. Discussion on two models of paleoclimatic records of magnetic susceptibility of Alaskan and Chinese loess (in Chinese). Quaternary, 2007, 27: 210-220

20 Liu X M, Liu T S, Paul H, et al. Two pedogenic models for paleoclimatic records of magnetic susceptibility from Chinese and Siberian loess. Sci China Ser D-Earth Sci, 2008, 51: 284-293

21 Ye W. Study on magnetic susceptibility of loess and paleosol sequences in westerly region of Xinjiang (in Chinese). J Desert Res, 2001, 21: 380-386

22 Shi Z T, Dong M, Fang X M. The characteristic of later pleistocene loess-paleosol magnetic susceptibility in Yili Basin (in Chinese). J Lanzhou Univ (Nat Sci), 2007, 43: 7-10

23 Song Y G, Shi Z T, Dong H M, et al. Loess magnetic susceptibility in Central Asia and its paleoclimatic significance. IGARSS, 2008, 2: $1227-1230$

24 Song Y G, Shi Z T, Fang X M, et al. Loess magnetic properties in the Ili Basin and their correlation with the Chinese Loess Plateau. Sci China: Earth Sci, 2010, 53: 419-431

25 Xia D S, Chen F H, Ma J Y, et al. Magnetic characteristics of loess in the Ily area and their environmental implication (in Chinese). Quaternary, 2010, 30: 902-909

26 Jia J, Xia D S, Wei H T, et al. A magnetic investigation of a loess/ paleosol sequences record in Ili area. Front Earth Sci, 2010, 4: 259-268

27 Li C S, Song Y G. Differences in magnetic susceptibility enhancement in Ili Loess, Xinjiang (in Chinese). Acta Geosci Sin, 2011, 32: $80-86$

28 Ye B H, Lai Z M, Shi Y F. Some characteristics of precipitation and air temperature in the Yili River Basin (in Chinese). Arid Land Geogr, 1997, 20: 47-52

29 Zhang J M. Study on temporal and spatial distribution of climate resource in Yili River Basin (in Chinese). Arid Meteorol, 2006, 24: 1-4
30 Ye W. Characteristic of physical environment and conditions of loess formation in Yili area, Xinjiang (in Chinese). Arid Land Geogr, 1999, 22: $9-16$

31 Fan L H. Study on comparison of the climatic variations and its effects in Tianshan Mountainous area, Southern and Northern Xinjiang (in Chinese). Master's Dissertation. Urumqi: Xinjiang University, 2006

32 Lv H H, Li Y L, Nan F, et al. Character and age of loess along north piedmont of Tianshan Mountains (in Chinese). Sci Geogr Sin, 2008, 28: $375-379$

33 Leonhardt R. Analyzing rock magnetic measurements: The RockMagAnalyzer 1.0 software. Comput Geosci-UK, 2006, 32: 14201431

34 Fabian K. Some additional parameters to estimate domain state from isothermal magnetization measurements. Earth Planet Sci Lett, 2003, 213: $337-345$

$35 \mathrm{Lu} \mathrm{H} \mathrm{Y,} \mathrm{An} \mathrm{Z} \mathrm{S.} \mathrm{Paleoclimatic} \mathrm{significance} \mathrm{of} \mathrm{grain} \mathrm{size} \mathrm{of} \mathrm{loess-}$ palaeosol deposit in Chinese Loess Plateau. Sci China Ser D-Earth Sci, 1998, 41: 626-631

36 Hao Q Z, Oldfield F, Bloemendal J, et al. Particle size separation and evidence for pedogenesis in samples from the Chinese Loess Plateau spanning the past $22 \mathrm{Ma}$. Geology, 2008, 36: 727-730

37 Maher B A. Magnetic properties of some synthetic sub-micron magnetites. Geophys J, 1988, 94: 83-96

38 Dunlop D J, Argyle K S. Thermoremanence, anhysteretic remanence and susceptibility of submicron magnetites: Nonlinear field dependence and variation with grain size. J Geophys Res, 1997, 102: 2019920210

39 Florindo F, Zhu R X, Guo B, et al. Magnetic proxy climate results from the Duanjiapo loess section, southernmost extremity of the Chinese Loess Plateau. J Geophys Res, 1999, 104: 645-659

40 Thompson R, Oldfield F. Environmental Magnetism. London: Allen and Unwin, 1986: 1-227

41 Evans M E, Heller F. Environemental Magnetism: Principles and Applications of Environmagnetics. London: Academic Press, 2003. $1-299$

42 Forster T, Heller F. Magnetic enhancement paths in loess sediments from Tajikistan, China and Hungary. J Geophys Res Lett, 1997, 24: 17-20

43 Pan Y X, Zhu R X, Shaw J, et al. Can relative palaeointensities be determined from the normalized magnetisation of the wind-blown loess of China? J Geophys Res, 2001, 106: 19221-19232

44 Cui Y L, Verosub K L. The effect of low-temperature oxidation on large mutli-domain magnetite. Geophys Res Lett, 1994, 21: 757-760

45 Velzen A J V, Dekkers M J. Low-temperature oxidation of magnetite in loess paleosol sequences: A correction of rock magnetic parameters. Stud Geophys Geod, 1999, 43: 357-375

46 Liu Q S, Banerjee S K, Jackson M J, et al. Effects of low-temperature oxidation on the natural remanent magnetization of the Chinese loess. Chin Sci Bull, 2002, 47: 2100-2105

47 Liu Q S, Banerjee S K, Jackson M J, et al. New insights into partial oxidation model of magnetites and thermal alteration of magnetic mineralogy of the Chinese loess in air. Geophys J Int, 2004, 158: 506-514

48 Deng C L, Vidic N J, Verosub K L, et al. Mineral magnetic variation of the Jiaodao Chinese loess/paleosol sequence and its bearing on long-term climatic variability. J Geophys Res, 2005, 110, B03103

49 Bloemendal J, King J W, Hall F R, et al. Rock magnetism of late Neogene and Pleistocene deep-sea sediments: Relationship of sediment source, diagenetic processes and sediment lithology. J Geophys Res, 1992, 97: 4361-4375

50 Hunt C P, Singer M J, Kletetschka G, et al. Effect of citrate-bicarbonate-dithionite treatment on fine-grained magnetite and maghemite. Earth Planet Sci Lett, 1995, 130: 87-94

51 Liu X M, Rolph T, Bloemendal J. The Citrate-Bicarbonate-Dithionite (CBD) removable magnetic component of Chinese loess. Quat Proc, 1995, 4: 53-58

52 Pinchas F, Kenneth L V, Michael J S. Pedogenic and lithogenic contribution to the magnetic susceptibility record of the Chinese loess/ 
palaeosol sequence. Geophys J Int, 1995, 122: 97-107

53 Liu Q S, Banerjee S K, Jackson M J, et al. An integrated study of the grain-size-dependent magnetic mineralogy of the Chinese loess/ paleosol and its environmental significance. J Geophys Res, 2003, 108: 2437

54 Liu Q S, Banerjee S K, Michael J, et al. Grain sizes of susceptibility and anhysteretic remanent magnetization carriers in Chinese loess/ paleosol sequences. J Geophys Res, 2004, 109: B03101

55 Liu Q S, Jackson M J, Yu Y J, et al. Grain size distribution of pedogenic magnetic particles in Chinese loess/paleosols. Geophys Res Lett, 2004, 31: L22603

56 Liu Q S, Jose T, Barbara A M, et al. Quantifying grain size distribution of pedogenic magnetic particles in Chinese loess and its significance. J Geophys Res, 2005, 110: B11102

57 Liu Q S, Deng C L, Torrent J, et al. Review of recent developments in mineral magnetism of the Chinese loess. Quat Sci Rev, 2007, 26: 368-385

58 Nie J S, Song Y G, John W, et al. Consistent grain size distribution of pedogenic maghemite of surface soils and Miocene loessic soils on the Chinese Loess Plateau. J Quat Sci, 2009, 25: 261-266

59 Spassov S, Heller F, Kretzschmar R, et al. Detrital and pedogenic magnetic mineral phases in the loess/palaeosol sequence at Lingtai (Central Chinese Loess Plateau). Phys Earth Planet In, 2003, 140: 255-275

60 Sun J M. Source regions and formation of the Loess sediments on the high mountain regions of northwestern China. Quat Res, 2002, 58: 341-351

61 Guo X L, Liu X M, Lv B, et al. Comparison of topsoil magnetic properties between the loess region in Tianshan Mountains and Loess Plateau, China, and its environmental significance (in Chinese). J Geophys, 2011, 54: 1854-1862

62 Zan J B, Fang X M, Yang S L, et al. A rock magnetic study of loess from the West Kunlun Mountains. J Geophys Res, 2010, 115: B10101

63 Jia J, Xia D S, Wei H T, et al. Magnetic properties of typical paleosol and loess stratum of western loess plateau and its signification to paleoclimate (in Chinese). J Lanzhou Univ (Nat Sci), 2010, 46: 26-40
64 Zan J B, Fang X M, Nie J S, et al. Magnetic properties of surface soils across the southern Tarim Basin and their relationship with climate and source materials. Chin Sci Bull, 2011, 56: 290-296

65 Verosub K, Fine P, Singer M, et al. Pedogenesis and paleoclimate: Interpretation of the magnetic susceptibility record of Chinese loesspaleosol sequences. Geology, 1993, 21: 1011-1014

66 Fassbinder J W E, Stanjek H, Vali H. Occurrence of magnetic bacteria in soil. Nature, 1993, 343: 161-163

67 Maher B A, Thompson R, Zhou L P. Spatial and temporal reconstructions of changes in the Asian palaeomonsoon: A new mineral magnetic approach. Earth Planet Sci Lett, 1994, 125: 461-471

68 Maher B A, Alekseev A, Alekseeva T. Magnetic mineralogy of soils across the Russian Steppe: Climatic dependence of pedogenic magnetite formation. Palaeogeogr Palaeoclimatol Palaeoecol, 2003, 201: 321-334

69 Torrent J, Barrón V, Liu Q S. Magnetic enhancement is linked to and precedes hematite formation in aerobic soil. Geophys Res Lett, 2006, 33: L02401

70 Torrent J, Liu Q S, Bloemendal J, et al. Magnetic enhancement and iron oxides in the upper Luochuan loess-paleosol sequence, Chinese Loess Plateau. Soil Sci Soc Am J, 2007, 71: 1570-1578

71 Torrent J, Liu Q S, Barrón V. Magnetic minerals in Calcic Luvisols (Chromic) developed in a warm Mediterranean region of Spain: Origin and paleoenvironmental significance. Geoderma, 2010, 154: 465-472

72 Liu Q S, Barrón V, Torrent J, et al. The magnetism of intermediate hydromaghemite in the transformation of 2-line ferrihydrite into hematite and its paleoenvironmental implications. J Geophys Res, 2008, 113: B01103

73 Bidegain J C, Rico Y, Bartel A, et al. Magnetic parameters reflecting pedogenesis in Pleistocene loess deposits of Argentina. Quat Int, 2009, 209: 175-186

74 Matasova G, Kazansky A. Contribution of paramagnetic minerals to magnetic properties of loess-soil deposits in Siberia and its paleoclimatic implications. Izv Phys Solid Earth, 2005, 41: 81-89

Open Access This article is distributed under the terms of the Creative Commons Attribution License which permits any use, distribution, and reproduction in any medium, provided the original author(s) and source are credited. 